\title{
Titer Antibodi Anjing Lokal Enam Bulan Pasca Vaksinasi Rabies
}

\section{(ANTIBODY TITER OF LOCAL DOGS SIX MONTHS ON RABIES VACCINATION)}

\section{Nengah Sudarmayasa ${ }^{1 *}$, Ida Bagus Kade Suardana ${ }^{2}$, I Nyoman Suartha ${ }^{3}$}

${ }^{1}$ Praktisi Dokter Hewan Kabupaten Bangli, Bali. ${ }^{2}$ Laboratorium Virologi Veteriner, ${ }^{3}$ Laboratorium Penyakit Dalam Veteriner, Fakultas Kedoteran Hewan Universitas Udayana, Jl. PB. Sudirman, Denpasar, Bali. *Email: nengahsudarmayasa78@gmail.com

\begin{abstract}
ABSTRAK
Rabies merupakan penyakit zoonosis yaitu, penyakit yang dapat ditularkan dari hewan ke manusia. Sebagian besar kasus rabies (98\%) disebabkan oleh gigitan anjing penderita rabies, sedangkan sisanya oleh kucing. Penelitian ini bertujuan untuk mengetahui titer antibodi anjing lokal enam bulan pasca vaksinasi rabies menggunakan vaksin rabisin. Penelitian ini dilakukan tiga tahap, yaitu: pengambilan sampel darah di Desa Buduk dan Sading, pemisahan serum dan pengujian serum dengan uji enzym linked immunosorbent assay (ELISA) menggunakan 19 sampel anjing lokal dengan pengambilan darah secara acak. Hasil penelitian menunjukkan dari 19 sampel yang diuji sebanyak 17 sampel (89\%) memiliki titer antibodi protektif (seropositif) dan dua sampel (11\%) belum memiliki titer antibodi protektif (seronegatif). Seropositif adalah nilai Optical Density (OD) di atas 0,5 IU, sedangkan seronegatif adalah nilai Optical Density (OD) di bawah 0,5 IU.
\end{abstract}

Kata kunci: Rabies; anjing lokal; titer antibodi; ELISA.

\begin{abstract}
Rabies is a zoonotic disease that can be transmitted from animals to humans. Most cases of rabies (98\%) were caused by the bite of dogs infected with rabies, while the rest by the cats. This study aims to determine the antibody titer six months y.o local dog after the rabies vaccination using vaccines rabisin. This research was conducted in three stages, namely: taking blood samples in the villages of Buduk and Sading, serum sampling and serum testing using an enzyme linked immunosorbent assay (ELISA) test using 19 samples of local dogs with random blood sampling. The results showed that from 19 samples tested 17 samples (89\%) had protective antibody titers (seropositive) and two samples (11\%) did not have protective (seronegative) antibody titers. Seropositive was the value of Optical Density (OD) above 0, $5 \mathrm{IU}$, while seronegative is the value of Optical Density (OD) below $0.5 \mathrm{IU}$.
\end{abstract}

Keywords: Rabies; local dogs; antibody titers; ELISA

\section{PENDAHULUAN}

Rabies merupakan penyakit zoonosis (penyakit yang dapat ditularkan dari hewan ke manusia). Penular utama rabies adalah anjing. Sebagian besar kasus rabies (98\%) disebabkan oleh gigitan anjing penderita rabies, sedangkan sisanya oleh kucing. Angka kematian pasien penderita rabies mencapai 100\% (Tanzil, 2014; Agustina et al., 2017). Program vaksinasi rabies di Bali secara massal terhadap semua hewan peka rabies telah dilakukan (Zakaria et al., 2005; Hibby et al., 2018; Utami et al., 2019). Di Kabupaten Badung, vaksinasi rabies pada anjing, sudah dilakukan sejak tanggal 4 Desember 2008, yang dilanjutkan dengan vaksinasi masal di semua Kabupaten/Kota di Provinsi Bali (Dartini et al., 2012).

Vaksinasi rabies telah dilakukan secara rutin, kejadian rabies pada anjing masih ada, dan penyebaran rabies pada bulan Januari tahun 2015 sampai Januari 2016 semakin meningkat. Faktor yang mempengaruhi hasil vaksinasi adalah faktor eksternal dan faktor internal. Faktor eksternal yaitu mutu vaksin, program vaksinasi tidak konsisten, dan kesalahan penanganan vaksin di lapangan sehingga tidak mampu merangsang terbentuknya kekebalan (Lestari dan Dharma, 2005; Utami dan Sumiarto, 2012). Faktor internal yaitu kondisi hewan, umur, dan status 
imun. Efikasi vaksinasi rabies menggunakan metode ELISA dilaporkan bahwa titer antibodi ELISA 0,5 IU/ml dapat memberikan perlindungan terhadap anjing selama enam minggu sampai dua tahun. Bila titer antibodi di bawah $0,5 \mathrm{IU} / \mathrm{ml}$ perlu dilakukan pengulangan vaksinasi/booster (Utami dan Sumiarto, 2012).

Respons imun anjing pasca vaksinasi rabies perlu diketahui secara berkala untuk mengetahui efektivitas vaksin dan kekebalan populasi yang terbentuk (Suardana et al., 2019). Berdasarkan hal diatas maka perlu dilakukan penelitian apakah anjing yang telah divaksinasi sudah memiliki titer antibodi protektif atau tidak.

\section{METODE PENELITIAN}

Penelitian menggunakan 19 sampel serum anjing lokal enam bulan pasca vaksinasi rabies. Pengambilan sampel dilakukan di desa Buduk dan Sading, Kecamatan Mengwi, Kabupaten Badung. Pengambilan sampel serum anjing dilakukan enam bulan pasca vaksinasi rabies. Darah anjing sebanyak $1-2 \mathrm{ml}$ diambil darivena cephalica antibrachii anterior kaki depan dengan menggunakan spuit steril berukuran $3 \mathrm{ml}$. Spuit yang telah berisi darah kemudian dibiarkan pada suhu kamar sampai serum keluar. Serum dipisahkan ke dalam eppendorf, kemudian disimpan pada suhu $-20^{\circ} \mathrm{C}$ sampai serum tersebut diuji.

Prosedur pemeriksaan serum dilakukan sesuai dengan panduanKIT ELISA Produksi Pusvetma Surabaya. Serum sampel di inaktivasi dengan mesin penghangat air (waterbath) dengan suhu $56^{\circ} \mathrm{C}$ selama 30 menit, kemudian diencerkan 1:50 dengan menambahkan $5 \mu 1$ sampel serum dengan $245 \mu 1$ pelarut. Serum kontrol positif diencerkan (sediaan $25 \mathrm{kali}$ ) dan serum kontrol negatif secara serial dari 50 kali, 100 kali, 200 kali dan 400 kali.

Serum sampel dan kontrol dimasukkan pada lubang mikroplate masing-masing $100 \mu 1$ dan dua lubang dibiarkan tanpa serum sebagai kontrol konjugat. Mikroplate ditutup dengan plastik penutup dan diinkubasikan pada suhu $37^{\circ} \mathrm{C}$ selama 45 sampai 60 menit. Cairan serum pada mikroplate uji dibuang dan dilakukan pencucian sebanyak minimal 5 kali. Cairan pencuci yang tersisa dalam jumlah kecil dalam mikroplate dikeringkan dengan cara membalikkan mikroplate di atas kertas tissue tebal. Konjugat yang telah diencerkan ditambahkan sebanyak $100 \mu 1$ per lubang. Mikroplate ditutup kembali dan diinkubasikan pada suhu $37^{\circ} \mathrm{C}$ selama 45 sampai dengan 60 menit. Cairan dibuang dan dilakukan pencucian minimal 5 kali dan ditambahkan substrat ABTS sebanyak $100 \mu 1$ pada setiap lubang. Platediinkubasikan pada suhu kamar, dalam kondisi gelap selama 30 menit. Terakhir ditambahkan $100 \mu$ stop solution pada setiap lubang.

Densitas optik (OD = Optical Density) dibaca pada pembaca (Reader) pada panjang gelombang $405 \mathrm{~nm}$. Selanjutnya dihitung Equivalent Unit (EU) dari masingmasing OD sampel dengan menggunakan rumus yang sudah disediakan dalam KIT. Titer serum 0,5EU atau lebih dianggap protektif. Pemeriksaan dilakukan di Laboratorium Balai Besar Veteriner Denpasar.

\section{HASIL DAN PEMBAHASAN}

Hasil penelitian menggunakan uji ELISA terhadap titer antibodi anjing lokal enam bulan pasca vaksinasi rabies menunjukkan, dari 19 sampel yang diambil di Desa Sading, Kecamatan Mengwi, Kabupaten Badung 17 sampel (89\%) memiliki titer antibodi protektif (seropositif) dengan rata-rata titer 2,49 \pm 3,57 dan 2 sampel (11\%) tidak memiliki titer antibodi protektif (seronegatif)dengan rata-rata titer $0,3 \pm 1,01$ Seropositifadalah nilai Optical Density (OD) di atas 0,5 EU, sedangkan seronegatif adalah nilai Optical Density (OD) dibawah 0,5 EU. 
Tabel 1 Rata-rata titer antibodi protektif dan tidak protektif anjing lokal enam bulan pasca vaksinasi rabies.

\begin{tabular}{llll}
\hline No & Sampel & Rata-rata titer & Persentase (\%) \\
\hline 1 & 17 seropositif & $2,49 \pm 3,57$ & $89 \%$ \\
2 & 2 seronegatif & $0,3 \pm 1,01$ & $11 \%$ \\
\hline
\end{tabular}

Titer antibodi protektif anjing yang divaksin rabies di Desa Sading memilikititer antibodi yang proktektif (OD $>0,5 \quad$ EU/ml) sebanyak $89 \%$. Pelaksanaan vaksinasi telah memberikan respon yang baik. Menurut WHO (2005) populasi anjing yang memiliki titer antibodi protektif $70 \%$ dapat mencegah munculnya penyakit rabies. Hal ini terbukti setelah dilakukan vaksinasi pada tahun 2016 dengan menggunakan vaksin rabisin terjadi penurunan kasus di Kabupaten Badung. Titer antibodi dalam penelitian ini lebih tinggi dibandingkan yang dilaporkan oleh Prasatya (2015) dan Wigaswari (2015) masing-masing $70 \%$ dan $50 \%$ menggunakan vaksin produsi yang berbeda.

Vaksin yang digunakan dalam penelitian ini adalah vaksin Rabisin Merial/Romindo Primavetcom bentuk sediaan cairan,komposisi tiap $\mathrm{ml}$ mengandung virus rabies inaktif, indikasi untuk pengebalan terhadap penyakit rabies dengan cara pemakaian secara subcutan (SC) atau intramuscular (IM). Kemungkinan besar yang mempengaruhi perbedaan titer antibodi protektif dengan penelitian sebelumnya adalah kualitas dari vaksin yang digunakan. Terbukti dari anjing yang baru divaksin pertama kali $85,7 \%$ telah menunjukan respon imun yang protektif.

Vaksin yang digunakan dalam vaksinasi tahun sebelumnya berbeda dengan vaksin pada tahun 2016 (Disnakpet, 2016). Faktor ini mungkin mempengaruhi titer antibodi atau nilai OD anjing yang telah divaksin lebih dari satu kali (Booster) tidak berbeda jauh dengan anjing yang divaksin pertama kali. Respon imun sekunder memberikan respon imun lebih cepat dan lebih tinggi apabila menggunakan antigen yang sama akibat adanya respon imun dari sel memori (Dartini et al., 2012). Disamping kualitas vaksin faktor lain yang mempengaruhi keberhasilan vaksinasi adalah ketrampilan vaksinator dan kesehatan dari hewan yang divaksin (Suardana, 2014).

Keragaman titer antibodi dari anjing dapat disebabkan oleh perbedaan umur, perbedaan pakan, adanya faktor infeksi, sistem pemeliharaan, dan nilai gizi. Secara umumdapat dikatakan bahwa kondisi anjing dengangizi yang cukup dan terawat dengan baik dapatmemacu komponen sistem imun berkembangdengan sempurna sehingga dapat berfungsisecara optimal. Ketika sistem kekebalan tubuhbekerja dengan baik, maka tubuh terlindungidan terhindar dari infeksi. Kekurangan gizi yangserius akan mengganggu respons imun dan produksi antibodi (Dibia et al., 2015). Halserupa dinyatakan pula oleh (Murphy et $a l ., 2007)$ bahwa hewan dengan defisiensi proteinatau defisiensi asam amino tertentumenyebabkan respon imun rendah dan hewan tersebut peka terhadapinfeksi virus.

Sebelas persen (2 dari 19) anjing yang memiliki seronegatif kemungkinan disebabkan oleh dosis vaksin yang tidak tepat atau anjing dalam kondisi stres. Dosis vaksin yang tidak tepat akan mempengaruhi terbentuknya titer antibodi, bila dosis vaksin kurang dari dosis yang dianjurkan maka berdampak tidak maksimalnya titer antibodi yang terbentuk. Anjing dalam keadaan stres pada saat dilakukan vaksinasi, mengakibatkan hormon glukokortikoid dan katekolamin meningkat dalam darah. Keadaan stres yang berkepanjangan dapat mengakibatkan terjadinya perubahan ekspresi gen pada sistem imun yang berakhir dengan 
disregulasi fungsi imun hewan (David et al., 2003).

\section{SIMPULAN}

\section{Simpulan}

Berdasarkan penelitian yang telah dilakukan, dapat disimpulkan bahwa titer antibodi anjing lokal enam bulan pasca vaksinasi rabies di desa Sading Kecamatan Menguwi Kabupaten Badung 89\% memiliki titer antibodi proktektif dan $11 \%$ memiliki titer antibodi tidak protektif terhadap rabies.

\section{Saran}

Anjing yang memiliki titer antibodi yang tidak protektif perlu divaksinasi ulang.

\section{DAFTAR PUSTAKA}

Agustina KK, Cahyani PSD, Suardana IBK. 2017. Dog demography and level of knowledge against rabies in positive and negative case of rabies areas in Mendoyo-Jembrana, Bali Indonesia. $J$ Vet. 18(4): 1-7.

Besung INKK, Suwiti NK, Suatha IK, Suastika IP, Piraksa IW, Setiasih NLE. 2011. Vaksinasi, edukasi dan eliminasi anjing liar sebagai usaha percepatan penanggulangan penyakit rabies di Bali. Udayana Mengabdi. 10(2): 57-60.

Centers for Disease Control and Prevention (CDC). 2011. The Rabies Virus.(http://www.cdc.gov/rabies/trans mission/virus.html.Diakses tanggal 18 april 2016).

Dibia IN, Sumiarto B, Susetya H, Putra AAG, Scott-Orr H. 2015. Faktor-faktor risiko rabies pada anjing di Bali. J. Vet. 16(3): 389-398.

David A, Padgett, Glaser R. 2003. How Stress Influences the Immune Response. Trends in Immunol. 24(8): 444-448.

Dartini NL, Mahardika IGNK, Putra AAG, Helen SO. 2012. Profil respons imun anjing yang divaksinasi dengan vaksin rabies (Rabivet Supra'92® danRabisin $\left.{ }^{\circledR}\right)$ pada kondis lapangan di Bali. Buletin Veteriner. 24(80): 9-15.
Dinas Peternakan Provinsi Bali (Dinak Prov. Bali). 2015. Rabies di Bali. http://www.disnak.baliprov.go.id/id/R ABIES-DI-BALI2.html. Diakses tanggal 19 april 2016.

Esther JJ, Verhallen V. 2001. The Complete Encylopedia of Dogs. The Netherlands. Rebo International

Hiby E, Agustina KK, Atema KN, Bagus GN, Girardi J,Harfoot M, Haryono Y, Hiby L, Irawan H, Kalalo L, Purnama SG, Subrata IM, Swacita IBN, Utami NWA, Januraga PP, Wirawan DN. 2018. Dog ecology and rabies knowledge of owners and non-owners in Sanur, a sub-district of the Indonesian island Province of Bali. Animals. 8(12): ani8070112.

Hiswani. 2003. Pencegahan dan Pemberantasan Rabies. USU digital library. http://libraryusu.ac.id/download/fkm/fkmhiswani10.pdf. diakses 8 april 2016

Murphy FA, Gibs EPJ, Horzinek MC, Studert MJ. 2006. Veterinary Virolog. $3^{\text {rd }}$ Ed. London: Academic press.

Prasatya IGMA. 2016. Titer antibodi anjing lokal jantan umur diatas satu tahun. Skripsi Program Sarjana Universitas Udayana.

Soedijar IL, Dharma DMN. 2005. Riview Rabies. Balai Besar Pengujian Mutu dan Sertifikat Obat. Lokakarya Nasional Penyakit Zoonosis. Pp. 119121.

Suartha IN, Anthara MS, Putra IGNN, Dewi NMRK, Mahardika IGNK. 2012. Pengetahuan masyarakat tentang rabies dalam upaya Bali bebas rabies Buletin Veteriner Udayana. 4(1): 41-46.

Shanker BR. 2009. Advances in diagnosis of rabies. Vet. World. 2(2): 74-78.

Suardana IBK. 2014. Pembuatan dan penggunaan antibodi monoklonal antivirus rabies isolat Bali untik mendiagnosis penyakit rabies pada anjing. Disertasi Doktor Ilmu Kedokteran Universitas Udayana Denpasar. 
Suardana IBK, Winaya IBO, Dewi DWP, Sudarmayasa IN, Agustina KK. 2019. Protective immune response of post rabies vaccinated dogs in Buduk Village Mengwi Badung Bali. J. Vet. 20(2): 264-268.

Sugiyama M, Yoshila R, Tatsumo Y, Hiraga S, Itoh O, Gamoh K. 1997. A new competitive ELISA demonstrated adequate immune levels to rabies virus in compulsory vaccinated in Japanese domestic dogs. Diagn. Lab Immunol. 4: 727-730.

Soeroso A. 2007. Sitokin. J. Oftalmologi Indonesia. 5: 172-174

Sridianti. 2016. Respon Imun Humoral dan Seluler

http://www.sridianti.com/respon-imunhumoral-dan seluler.html. Diakses tanggal 18 april 2016

Tarigan IM, Sukada IM, Puja IK. 2012. Cakupan vaksin anti rabies pada anjing dan profil pemilik anjing di daerah kecamatan Baturiti, Tabanan. Indonesia Medicus Veterinus. 1(4): 530-541.

Tanzil K. 2014. Penyakit rabies dan penatalaksanaannya. E-Journal WIDYA Kesehatan Dan Lingkungan. 1: 61-67.
Utami S, Sumiarto B. 2012. Tingkat dan faktor resiko kekebalan protektif terhadap rabies pada anjing di kota Makasar. J. Vet. 13: 7-79.

Utami NWA, Agustina KK, Atema KN, Bagus GN, Girardi J, Harfoot M, Haryono Y, Hiby L, Irawan H, Januraga PP, Kalalo L, Purnama SG, Subrata IM, Swacita IBN, Swarayana IMI, Wirawan DN and Hiby E. 2019. Frontiers. Vet. Sci. 6(193): 1-12.

Wirata IK, Uliantar GAJ, Sudiarka IW, Sudira IW, Widia IK. 2011. Distribusi rabies di Bali: Sebuah analisis berdasarkan hasil pengujian laboratorium. Buletin Veteriner. 23: 2728.

Wigaswari NDN. 2016 Respon imun anjing lokal betina umur diatas satu tahun. (Skripsi) Program Sarjana Universitas Udayana.

Wandeler AI, Matter HC, Kappeler A, Budde A. 1993. The ecology of dogs and canine rabies: a selective review. Rev. Sci. Tech. 12(1): 51-71. 